\title{
DE MOZOS PICADOS, GUARDAS APEDREADOS \\ Y GOBERNANTES PISOTEADOS. LA CATÁRTICA \\ VIOLENCIA LÚDICO-FESTIVA EN EL QUIJOTE
}

On enraged muleteers, stoned guards, and trampled rulers.
The cathartic, ludic-festive violence in Don Quixote

† Gabriela NaVA*

\section{RESUMEN}

A través de la relectura de diversos episodios, el presente texto pretende exponer cómo la función de la violencia en el Quijote no se agota en la tergiversación paródica de los combates caballerescos. La idea de la violencia como energía catártica constituye un elemento clave para comprender la razón simbólica por la cual ciertos personajes se convierten en víctimas durante los combates, las palizas y los apedreamientos de la novela cervantina.

Palabras Clave: violencia, Quijote, Carnaval, Chivo expiatorio.

\section{Abstract}

After careful re-reading, this paper aims to expose how the role of violence in Don Quixote is not limited to a parodic tergiversation of knightly combats. The concept of violence as cathartic energy is a key element to understand the symbolic motive for certain characters to become underdog in combats, beatings, and stoning episodes in the Cervantine novel.

Key Words: VIOLENCE, Don QuiXote, CARNival, SCAPEgoat.

Recepción: 12 de noviembre de 2015.

Dictamen 1: 9 de diciembre de 2015.

Dictamen 2: 29 de diciembre de 2015.

* Universidad Nacional Autónoma de México, Instituto de Investigaciones Filológicas. Correo electrónico: lepus39@yahoo.com 
Interesantes son las láminas del libro Habiti d'bvomeni et donne venetiane con la processione della serenissima signoria et altri particolari cioè trionfifeste et cerimonie publiche della nobilissima città di Venetia (1609), que muestran aspectos de la vida pública en la entonces república veneciana. ${ }^{1}$ Entre éstas destacan las ilustraciones sobre diversos juegos festivos, todos ellos impregnados de una gran carga de violencia. En una de ellas, Giacommo Franco retrató detalladamente cómo los venecianos se divertían saltando desde un puente con el propósito de alcanzar un ganso atado de cabeza y retorcerle el cuello; luchando con la cabeza rapada contra un gato amarrado a un palo, y observando cómo un par de perros atacan a un oso. El grabador italiano dibujó, en una segunda lámina, la tradicional batalla de dos bandos para echar al adversario de un puente y tomar el control de éste.

Es posible encontrar múltiples testimonios de prácticas similares, celebradas desde la Edad Media hasta épocas recientes en España, Inglaterra, Francia y otros países durante las festividades carnavalescas. Actos que van desde una agresividad leve hasta aquellos que causan un daño físico considerable a las personas. Ejemplo de lo anterior es la prevaleciente tradición gallega de que hombres y mujeres confeccionan muñecos del sexo contrario, los cuales son objeto de disputa, hasta el punto en que luchan a golpes entre sí para robarlos. Durante los siglos XV y XVII, en ciudades como Lyon existía la costumbre de hacer desfilar a los varones mientras sus esposas los golpeaban con palos, tripas, cucharas y sartenes. Como parte del Carnaval de Roma, los judíos eran obligados a participar en carreras en las que se les sometía a diversas vejaciones, desde correr semidesnudos, ser perseguidos por caballos, hasta que los espectadores les arrojaran piedras y lodo. De igual manera, en zonas como Asturias solían entablarse encarnizadas peleas a puñetazos entre los habitantes de pueblos vecinos. ${ }^{2}$ Al examinar en conjunto estas manifestaciones de violencia real o simulada podría decirse que todas ellas tienen su correlato en los conflictos y las fricciones entre una colectividad determinada y algún otro. Esta relación de rivalidad se desdobla en diferentes contraposiciones de edad, sexo, gremios, barrios, facciones o grupos sociales. Mucho más que una mera representación de animadversiones existentes, los ritos de violencia festiva permiten a los participantes expresar y dar rienda suelta a la agresividad soterrada que albergan de manera habitual hacia sus antagonistas. De este modo, los duelos de insultos,

${ }^{1}$ La serie íntegra de láminas puede consultarse en los archivos digitales de la Bibliothéque Nationale de France: http://gallica.bnf.fr/ark:/12148/btvlb84467592/f20.item.

2 Diversos especialistas, como Edward Muir (2001), Peter Burke (1996; 200) y Julio Caro Baroja (1979) han estudiado en profundidad las costumbres carnavalescas de los pueblos europeos a lo largo de la historia. 
la quema de monigotes, los combates a pedradas, las batallas con palos y demás ritos adquieren un carácter terapéutico. ${ }^{3}$

Conviene destacar que esta violencia, lúdica a la vez que catártica, subyace también en las escenas de palos, propias del teatro breve. Es menester aclarar que si bien ningún personaje suele escapar de la distribución de los golpes, en muchos casos las contiendas se llevan a cabo entre parejas contrapuestas (mujer-hombre, estudiantesoldado, amo-criado), o bien la víctima de los vapuleamientos encarna defectos personales o sociales (el bobo, el doctor). Como ha hecho notar Justo Fernández Oblanca, "los palos literarios" propinados a alcaldes, jueces y alguaciles "podían ser valorados como una terapia para liberar agresividad en la gran masa de espectadores que no tenían 'satisfacciones' de esta naturaleza en la vida real” (1992, p. 194).

$\mathrm{Al}$ analizar las manifestaciones de esta violencia lúdica resulta insoslayable asociarla con las burlescas palizas y golpizas que padecen diversos personajes en el Quijote, en especial el propio caballero manchego. Sobra decir que en el desarrollo de las batallas y los combates caballerescos en la novela se verifica una subversión paródica de la condición social de los adversarios, el tipo de las cabalgaduras y el manejo de las armas. ${ }^{4}$ Sin embargo, estas tergiversaciones no poseen sólo dicha dimensión paródica. La facultad catártica inherente a la violencia lúdico-festiva constituye un elemento clave sin el cual es imposible revalorar el sentido irrisorio que adquieren los vapuleamientos y combates en el texto cervantino.

\footnotetext{
3 Pese a su carácter ritualizado, la violencia festiva puede desembocar en actos de violencia real. Durante los siglos XVI y XVII, diversos carnavales derivaron en motines, rebeliones y ajusticiamientos debido a las tensiones sociales y económicas imperantes en diferentes poblaciones. Tal es el caso del Carnaval Cruel (1511), en el que los campesinos de Udine se sublevaron contra ciertas facciones nobiliarias. En estas sublevaciones asesinaron a varios de sus miembros e incendiaron sus castillos. Los cadáveres se dejaron en la calle para que perros y cerdos los devoraran (Muir, 2001, pp. 129-131). Otro caso es el Carnaval de Romans (1580), donde los habitantes de la ciudad protagonizaron una revuelta ante la excesiva carga tributaria (Le Roy, 1994).

${ }^{4}$ Es importante aclarar que la digresión cómica de los modelos caballerescos no es un procedimiento exclusivo de la novela cervantina. En los mismos libros de caballerías es común encontrar "risibles infracciones del código caballeresco en materia de indumentaria, armamento, modales y, sobre todo, asomos de cobardía” (Márquez Villanueva, 1973, p. 340). Con respecto del desarrollo de los combates, puede citarse, en el Florisel de Niquea, el episodio en el que Fraudador apedrea a un caballero hasta derribarlo (II, cap. XL). En el Platir, los combates singulares adquieren un carácter humorístico cuando Gradior, el Caballero Encubierto, emplea la magia para burlarse de sus adversarios, con lo cual evita que logren romper las lanzas y acertar un golpe con la espada (I, cap. LVIII).
} 


\section{LA VIOLENCIA LÚDICO-FESTIVA: ELEMENTO TERAPÉUTICO DE LA SOCIEDAD}

Desde una perspectiva etiológica, la violencia no constituye un fenómeno fortuito o sin razón; muy por el contrario, es un acto cuya función social está bien determinada (Rodrigo, 2003, p. 18). La construcción de la sociedad presupone la instauración de distinciones diferenciales, normas y prohibiciones. Inevitablemente, estos factores crean tensiones y conflictos entre los miembros de la comunidad. La armonía social depende de la manera en que los individuos sobrelleven dichas disensiones. En este sentido, la violencia emerge como un mecanismo capaz de nivelar el rencor y dar escape al descontento que crecen gradualmente durante la vida cotidiana.

Puesto que la violencia es un vehículo de liberación de los resentimientos surgidos de las desavenencias diarias, aquella no se dirige a un blanco elegido al azar. De manera preintencionada, la colectividad encauza la violencia hacia un objetivo específico: el "chivo expiatorio", el cual es "sacrificado" (insultado, vejado y golpeado). De acuerdo con René Girard, el sacrificio del chivo expiatorio trae consigo la purificación de la comunidad en tanto que su muerte simboliza la eliminación, aunque sea temporal, de los elementos conflictivos representados en su figura, que provocan la crisis en el interior de la sociedad y enemistan a los integrantes de esta. ${ }^{5}$ A partir de lo anterior puede afirmarse que la violencia, aun cuando tiene efectos en apariencia destructivos, constituye, en última instancia, un acto restaurador del orden social (Girard, 1998, p. 43). La dimensión catártica de la violencia se denota con claridad en su faceta ritualizada: sacrificios, ejecuciones, penitencias, competiciones deportivas. ${ }^{6}$ Precisamente esta acción catártica constituye la esencia de la violencia carnavalesca.

En términos generales, la violencia inherente al sacrificio del chivo puede considerarse un mecanismo por el cual la colectividad supera la crisis. Ahora bien,

\footnotetext{
5 René Girard ha explicado con detalle la figura del chivo expiatorio en sus libros La violenciay lo sagrado (1972) y El chivo expiatorio (1982). En diversas culturas, el chivo expiatorio se considera el culpable de los males de la sociedad. Por esta razón, el orden se restaura cuando es sacrificado. El chivo se distingue del resto de la comunidad por una característica, evidente o imperceptible, llamada rasgo victimario. Por ejemplo, el deforme es un ser excluido debido a su aspecto físico (Girard, 2002,pp. 28-29). Al hablar del chivo expiatorio, Girard aclara que un miembro puede ser excluido del grupo al encontrase "por arriba" o "por abajo" en la estructura del sistema (1998, pp. 19-20).

6 Sin entrar en detalles acerca de las modalidades que la violencia puede asumir, podría decirse que la sociedad recurre a la ritualización en un intento por controlar e integrar de manera legitimizada el ejercicio de la violencia en la vida comunitaria. Mediante la ritualización se autoriza a los participantes y espectadores a liberar su agresividad dentro de parámetros aceptables. Los lugares públicos y sagrados constituyen los escenarios principales de la violencia así "domesticada".
} 
la violencia carnavalesca se distingue por cuanto su acción catártica no depende únicamente de la eliminación del chivo. Debe tenerse en mente que el objetivo del carnaval es la regeneración del mundo al reactualizar el orden primigenio. Siguiendo este principio, la violencia carnavalesca da muerte simbólica a los personajes que (con razón o sin ella) se consideran perturbadores del orden, para permitir que nazca su contraparte renovada. Mijaíl Bajtín capta la dinámica de este doble proceso destructor-creador al plantear que los golpes "matan y dan una nueva vida, terminan con lo antiguo y comienzan con lo nuevo” (1998, pp. 184-185). Esta cualidad ambivalente permea en las manifestaciones de la violencia lúdico-festiva en el Quijote, de modo que es equiparable con una fuerza que recorre el contramundo creado por el caballero manchego, desarmándolo, en una especie de exorcismo alegre, para reordenarlo y renovarlo.

Volviendo a la idea inicial, las características de ciertos personajes en el Quijote los convierten en víctimas significativas de la violencia desde la perspectiva del chivo expiatorio y su sacrificio festivo. Sin pretender reducir la interpretación de los enfrentamientos caballerescos paródicos a una lucha de clases, este conjunto de personajes representa un conflicto o una rivalidad bien determinados en el orden social, ya sea en el plano vertical u horizontal. En este sentido, el apaleamiento de don Quijote a manos del mozo de mulas (I, 4) y el duelo entre el hidalgo y el vizcaíno (I, 8-9), entre otros ejemplos, cobran relevancia debido a la dinámica de las relaciones establecidas.

El interés de este trabajo es exponer cómo los personajes realizan, mediante la transfiguración de la violencia caballeresca en festiva, una catarsis lúdica de los conflictos que afectan a la España de los siglos XVI y XVII. En este punto es importante aclarar, sin embargo, que no todas las manifestaciones de violencia en la novela cumplen una función catártica y lúdica. A lo largo del Quijote, la violencia se muestra como una fuerza que adopta diversas formas, provenientes de la realidad social (azotes, penitencias, palizas), los libros de caballerías (combates con lanzas y espadas) y las festividades carnavalescas (pedreas, cencerradas). ${ }^{7}$

\footnotetext{
7 En el caso específico de la España del Siglo de Oro, la violencia física era un motivo cotidiano, del cual la autoridad, real o eclesiástica, se valía para afirmar su poder dentro de lo que Augustin Redondo ha denominado "una pedagogía del miedo" (1998, p. 172). Como se ha señalado, en el Quijote no se le puede otorgar un carácter único a la violencia. La "multiplicidad, complejidad y heterogeneidad" de la violencia ha sido analizada por B. Torres y M. E. Guillemont, 2008, p. 745 .
} 


\section{EL PAROXISMO DE LA VIOLENCIA LÚDICO-FESTIVA}

Diversos especialistas - entre ellos Augustin Redondo y James Iffland- concuerdan en que la cultura carnavalesca influyó en la configuración del Quijote. A manera de ejemplo pueden citarse la caracterización de la pareja quijotesca y el desfile de carros y personajes enmascarados celebrado en el palacio ducal. En lo que se refiere a la violencia festiva, varios rituales sirven de modelo a las aventuras del caballero manchego y su escudero. A la usanza de los ataques dirigidos contra animales y muñecos, Sancho corre la misma suerte que un "perro en Carnestolendas" cuando es manteado por un grupo de perailes y agujeros, "gente alegre, bien intencionada, maleante y juguetona”, durante su primera visita a la venta de Juan Palomeque (I, 17, p. 184). En el mismo tenor, el actor vestido de bojiganga asusta y vapulea con tres vejigas de vaca hinchadas a Rocinante y al rucio de Sancho (II, 11).

En las dos escenas, la violencia se presenta como una acción lúdica que divierte a los perailes, los agujeros y al actor. Extrapolando lo dicho, es posible plantear que los personajes, bajo el amparo del juego, dejan aflorar la hostilidad latente en la vida cotidiana, dirigiéndola arbitrariamente hacia Sancho, Rocinante y el rucio. El manteamiento y el vapuleamiento reflejan la búsqueda continua de salidas simbólicas a las tensiones y animadversiones. En términos de Gerard Imbert, podría plantearse que ambas agresiones constituyen una "manera de engañar" a la violencia con la "propia violencia" (1992, p. 27). Dicho de otro modo, se trata de mecanismos preventivos cuyo propósito es conjurar un conflicto mayor entre los miembros de la comunidad.

El alivio pasajero que brinda la liberación de la tensión emocional mediante la violencia queda ilustrado con claridad en la figura del mozo de mulas que vapulea a don Quijote (I, 4). Cabe señalar que desde la perspectiva del chivo expiatorio, el caballero manchego atrae la violencia hacia a sí debido a ciertos rasgos victimarios: ${ }^{8}$ la vejez, la locura y su condición social. Estos dos últimos rasgos "justifican" que el hidalgo sea el blanco del ataque del mozo.

Un mozo de mulas de los que allívenían, que no debía de ser muy bienintencionado, oyendo decir al pobre caído tantas arrogancias, no lo pudo sufrir sin darle la respuesta en las costillas. Y,llegándose a él, tomó la lanzay, después de haberla hecho pedazos, con uno dellos comenzó a dar a nuestro don Quijote tantos palos, que, a despecho y pesar de sus armas, le molió como cibera. Dábanle voces sus amos que no le diese tanto y que le dejase; pero estaba ya el mozo

8 Véase la nota 5 . 
picado y no quiso dejar el juego hasta envidar todo el resto de su cólera; y acudiendo por los demás trozos de la lanza, los acabó de deshacer sobre el miserable caído, que, con toda aquella tempestad de palos que sobre él llovía, no cerraba la boca, amenazando al cielo y a la tierra y a los malandrines, que tal le parecían.

Cansose el mozo, y los mercaderes siguieron su camino, llevando que contar en todo él del pobre apaleado $[\ldots](\mathrm{I}, 4, \mathrm{p} .70)$.

En el tiempo ordinario, la violencia dirigida hacia los representantes de las capas superiores se considera un acto subversivo, pero en la realidad otra, de carácter lúdico, resultante de la locura quijotesca, la permutación y confusión de identidades hacen que don Quijote pierda su fuero, a la vez que otorgan licencia al mozo para violar las de otro modo infranqueables barreras jerárquicas. Visto así, el mozo de mulas puede equipararse con la colectividad que aprovecha el contramundo creado temporalmente para liberar el descontento acumulado hacia el sistema que debe soportar a diario, encarnado en el personaje del hidalgo: "oyendo decir al pobre caído tantas arrogancias, no lo pudo sufrir sin darle la respuesta en las costillas".

Con respecto de la purga de las emociones que conlleva el despertar de la violencia, nada más significativo que la descripción del mozo apaleando a don Quijote: "no quiso dejar el juego hasta envidar todo el resto de su cólera". La imagen del "mozo picado" - quien recoge hasta el último trozo de la lanza para romperlo sobre el caballero manchego- ilustra visualmente la euforia que subyace a la acción de desahogar por completo el resentimiento.

Debe añadirse que la paliza posee una doble dimensión paródica y simbólica. El motivo de "romper lanzas" se ve tergiversado cuando el arma, en vez de hacerse trizas durante un combate, es quebrada en múltiples trozos sobre el cuerpo de don Quijote. La "tempestad de palos” evoca irrisoriamente la violencia entremesil. Dejando aparte el carácter paródico, la paliza resulta significativa en cuanto que el caballero es golpeado con el propio símbolo de su condición social. Atendiendo a esta idea, la ruptura de la lanza podría entenderse como la degradación burlesca de la autoridad. ${ }^{9}$ En suma, la paliza que recibe don Quijote constituye una jocosa

\footnotetext{
9 Algunos críticos han asociado la lanza de don Quijote con objetos representativos del mundo carnavalesco. Según James Iffland, la lanza es una variante del cetro típico del rey del Carnaval (1999, p. 68), mientras el lanzón remite al utensilio empleado para sostener las viñas y, por ende, evoca las imágenes de Baco y Saturno (78). Por su parte, Bénédicte Torres relaciona la lanza con el palo enarbolado por el loco, justificando así que don Quijote prefiera usar la lanza sobre la espada en sus enfrentamientos (2002, p. 30). Cabe recordar que los caballeros, antes de iniciar el paso honroso, estipulaban el número de lanzas que debían romperse para considerarlo concluido. En el paso quijotesco, la lanza hecha pedazos reformula de manera paródica esta convención
} 
válvula de escape para una animadversión que no puede resolverse durante el tiempo ordinario. La reformulación paródica de la violencia caballeresca en festiva vuelve a brindar una resolución lúdica a la creciente animosidad entre los estamentos sociales en el episodio del vizcaíno (I, 8-9).

\section{DE LA DISPUTA ENTRE HIDALGOS CON ARMAS LLENAS DE MOHO Y VIZCAÍNOS AFORRADOS CON ALMOHADA}

A lo largo de sus andanzas, don Quijote busca emular una serie de acciones heroicas vinculadas con los pasos honrosos, los combates singulares y las batallas campales. De manera completamente accidental, diferentes personajes de la novela (arrieros, frailes benedictinos, disciplinantes) quedan envueltos en una atmósfera de apedreamientos, palizas y golpizas. En lo relativo a la participación de los personajes en estos enfrentamientos, llama la atención que el vizcaíno sea el único dispuesto a entablar combate "verdadero" con don Quijote (I, 8-9). ${ }^{10}$

El encuentro entre don Quijote y el escudero vizcaíno ocurre cuando el héroe pretende liberar a las "altas princesas" que van cautivas por algunos encantadores, sin percatarse de que en realidad son una señora acompañada por algunos mozos y dos frailes benedictinos. Tras derrotar a los supuestos encantadores, el caballero manchego cree que ha cumplido su cometido y solicita a la dama presentarse ante Dulcinea para contarle que él la liberó. No obstante, es interrumpido por el escudero, quien le exige que los deje seguir su camino, amenazándolo de muerte si no cumple la demanda. La discusión se eleva de tono cuando don Quijote dice que no puede castigar al atrevido vizcaíno, ya que éste no es caballero. Ante la descalificación, el escudero reacciona acusándolo de mentiroso. Como respuesta, don Quijote arremete con la espada en su contra.

Empero, si bien la locura es el motor inmediato del desafío de don Quijote al vizcaíno, la desavenencia entre ambos no es casual. Existe un trasfondo histórico. Para comprender esa animadversión debe tenerse en cuenta la polémica de la época sobre la nobleza universal de los vascos, ${ }^{11}$ quienes asumían merecer el carácter de

10 Es importante aclarar que excluyo la figura de Sansón Carrasco en cuanto él no queda atrapado "accidentalmente" en la violencia caballeresca. Con el propósito original de burlarse de don Quijote, el bachiller reta a combate al hidalgo enloquecido, haciéndolo creer que es el Caballero de los Espejos (II, 14). Posteriormente, para vengar su derrota, Sansón adopta el disfraz del Caballero de la Blanca Luna y se enfrenta de nuevo a don Quijote (II, 64).

11 El reconocimiento de la hidalguía implica más bien ausencia de condición plebeya que la existencia de linaje reconocido. Dicho de otro modo, establecía un igualitarismo entre todos los vascos. La naturaleza noble de los 
hidalguía por el simple hecho de ser originarios de Vizcaya o descendientes de los pobladores de dicha región. Su condición les otorgaba los mismos privilegios de cualquier noble: trato favorable de la justicia, exención tributaria, del servicio militar y del tormento. La supuesta nobleza de los vizcaínos se convierte en fuente de discordia en una sociedad que ve cómo cambian las diferencias sociales y cómo éstas permiten a algunos de sus miembros situarse sobre otros.

Tomando en cuenta lo anterior, es posible plantear que don Quijote encarna la actitud defensiva de los hidalgos, quienes arruinados por la evolución económica han perdido muchas prerrogativas del estamento noble y desean mantener las barreras jerárquicas, mientras el vizcaíno personifica un grupo que ostenta una hidalguía limpia e impoluta, incompatible con la pobreza que los obligaba al ejercicio de oficios viles. En términos generales, el choque de intereses convierte al caballero manchego y al vizcaíno en antagonistas.

El antagonismo entre el caballero manchego y el vizcaíno puede identificarse con el conflicto definido por Girard, que enfrenta a ciertos grupos de la sociedad cuyos intereses convergen en un mismo objeto. Un grupo o facción se vuelve el obstáculo para el cumplimiento del deseo del otro, lo cual da lugar a una rivalidad sin solución y, en último término, a la desarmonía social. En el interior de esta dinámica, la violencia emerge como mecanismo de reconciliación provisional al conflicto continuo. La contienda hace cierta la afirmación de Hannah Arendt acerca de que la violencia sirve para dramatizar las preocupaciones sociales y exponerlas a la atención pública (2006, p. 107). Entonces, el duelo entre don Quijote y el vizcaíno puede verse como un juego de agresión recíproca que permite paliar la competencia por el estatus de hidalguía, reclamado por ambos personajes.

El marco de la parodia caballeresca da lugar a que el conflicto entre los dos grupos y su resolución sean escenificados en términos irrisorios. Conviene destacar que el mismo motivo de la disputa aparece caricaturizado; el aspecto de los personajes muestra una hilarante imagen de la condición de hidalguía. De este modo, el vizcaíno aforrado con la almohada y montado sobre la arisca mula de alquiler se vuelve un doble burlesco de la figura del caballero manchego, ya de por sí ridícula, que cabalga al decrépito Rocinante y ostenta una armadura enmohecida:

vascos tiene su justificación en que Vizcaya no habían habitado judíos ni moros, por lo cual existía la pureza de sangre (Soria, 2006, pp. 291-292). 
[...] Elvizcaino, que asíle vio venir contra él, bien entendió por su denuedo su coraje, y determinó de hacer lo mesmo que don Quijote; y, así, le aguardó bien cubierto de su almohada, sin poder rodear la mula a una ni a otra parte, que ya, de puro cansada y no hecha a semejantes niñerías, no podia dar un paso.

Venía, pues, como se ha dicho, don Quijote contra el cauto vizcaíno con la espada en alto, con determinación de abrirle por medio, y el vizcaino le aguardaba ansimesmo levantada la espada y aforrado con su almohada [...] (I, 8, p. 103).

[...] No se diga más sino que fue de manera que se alzó de nuevo en los estribos y, apretando más la espada en las dos manos, con tal furia descargó sobre el vizcaino, acertándole de lleno sobre la almohaday sobre la cabeza [...] (I,9, p. 111).

El desfase entre la cólera que embarga a los contendientes y el desarrollo paródico del combate (la cansada mula de alquiler incapaz de caminar, la almohada empleada cual si fuera escudo, el vizcaíno cayendo al suelo por los corcovos de la mula) arrebata cualquier dimensión grave a la lucha antagónica.

Hasta ahora se ha expuesto que la violencia lúdico-festiva sirve para apaciguar las tensiones entre los miembros de la sociedad. Sin embargo, su efecto catártico no se limita a la liberación momentánea de las emociones (cólera, envidia, rencor, odio). En la vida cotidiana, los principios del orden social se corrompen, desgastan y, de manera inevitable, se convierten en copias imperfectas de lo que debieran ser. Desde la perspectiva de lo ritualizado, la violencia dirigida hacia los personajes revestidos de una cierta carga simbólica crea la ilusión de ejercer un efecto purificador sobre los principios representados en esas figuras. Esta idea otorga un significado particular a la ola de violencia que envuelve a los guardas y a don Quijote en el episodio de los galeotes (I, 22).

\section{ENDEREZANDO LOS “JUICIOS TORCIDOS” DE LA JUSTICIA: LA ACCIÓN CATÁRTICA EN EL EPISODIO DE LOS GALEOTES}

Ayudó Sancho por su parte a la soltura de Ginés de Pasamonte, que fue el primero que saltó en la campaña libre y desembarazado, y, arremetiendo al comisario caído, le quitó la espaday la escopeta, con la cual, apuntando al uno y señalando al otro sin disparalla jamás, no quedó guarda en todo el campo, porque se fueron huyendo, así de la escopeta de Pasamonte como de las muchas pedradas que los ya sueltos galeotes les tiraban (I, 22, p. 245). 
La imagen del Ginés de Pasamonte amenazando con la escopeta a los guardas evoca las típicas inversiones del mundo al revés: los reos sometiendo a los representantes de la autoridad (I, 22). Aunque sea de manera efímera, el giro de papeles da lugar al cómico descoyuntamiento del orden social. La escena de los galeotes apedreando a los guardas pareciera seguir el esquema expuesto de liberar la hostilidad reprimida. Mas la acción catártica de la violencia no se articula únicamente en torno al antagonismo de los personajes. Profundizando el análisis, el apedreamiento de los guardas encuentra su correlato en las razones por las cuales los galeotes van condenados a las galeras.

El grupo de hombres encadenados - con quienes se cruza en su caminodespierta la curiosidad de don Quijote de conocer las razones por las cuales se les ha condenado a trabajar como remeros en las naves del rey. Al margen de otros aspectos, los diferentes casos expuestos convergen en un mismo punto: el retrato de una "justicia desviada”. Así pues, la historia narrada por el ladrón de la canasta de ropa pone de manifiesto la relación desproporcionada que solía existir entre el crimen cometido y el tiempo de sentencia en las galeras. Por otra parte, la confesión del cuatrero pone en duda la validez de las confesiones obtenidas mediante la tortura. En este mismo tenor, a través del caso del tercer galeote, quien no explica su delito, se cuestiona la legitimidad de las sentencias de los acusados que no poseen el dinero suficiente para sobornar a las autoridades.

De acuerdo con Ludovik Osterc, el episodio obliga a reflexionar, por una parte, sobre si "¿Una sociedad corrompida e injusta, tiene derecho de castigar con tan duras penas a los infractores de sus leyes?" y, por otra parte, sobre si "¿Tiene derecho de castigar, en general, una sociedad, cuyas clases directas y aparato estatal como su instrumento de coerción, podridos hasta la médula, constituyen la personificación misma de la injusticia?” (1988, p. 246).

En suma, la relación de los delitos y las subsecuentes penas exponen tanto la parcialidad de los tribunales como la arbitrariedad de las severas condenas dictadas. El imperfecto sistema de administración de justicia que corrompe sus facultades queda personificado en la figura de los guardas que escoltan a los galeotes y se niegan a liberarlos. ${ }^{12}$ Considerando su acción catártica, la violencia que emerge

12 Los temas de la justicia y del antijerarquismo en la aventura de los galeotes han sido abordados desde diversas perspectivas. Para algunos críticos “-Ganivet, Unamuno, Américo Castro-don Quijote, campeón de la justicia 'en si' [...] denuncia, de palabray de obra, la inevitable imperfección de cualquier justicia humana, mientras que para [...] otros - Azorín, Osterc, Francisco Olmos García- es la justicia de los Austrias y de sus esbirros la que viene condenada de este modo, y esto en términos demasiado expresivos para autorizar generalizaciones arbitrarias. Sin embargo, todos coinciden en considerar que no cabe deducir de la desventura final del caballero el significado y 
cuando don Quijote arremete contra los guardas tiene el propósito de aniquilar la justicia desviada, cuyos órganos y procedimientos necesitan ser enmendados y enderezados para cumplir cabalmente sus funciones.

El ataque de don Quijote hacia los guardas da inicio al desmantelamiento del torcido sistema sancionador. Asimismo, la violencia propicia el surgimiento de un sentido de communitas entre los galeotes, quienes se unen para destituir a los ejecutores de la justicia desviada. A través del apedreamiento, Ginés de Pasamonte y el grupo de reos despojan a los guardianes de su autoridad simbólica, en una escena que remite, como se ha señalado, a las inversiones del mundo al revés. ${ }^{13}$

Pero la ola de violencia catártica no se detiene con la liberación de los galeotes y la huida de los guardas. Bajo el principio de que la aniquilación del viejo mundo antecede al nacimiento de uno nuevo, la depuración de los aparatos de justicia demanda eliminar toda figura representativa del poder coercitivo. El caballero manchego atrae hacia a sí la violencia al desempeñarse como contraparte de la imperfecta justicia pública.

Cual si fuera el pelele que es golpeado durante el ritual del destronamiento festivo, don Quijote se convierte en el centro de un juego de despedazamiento progresivo organizado por los galeotes. En respuesta a la petición de presentarse ante Dulcinea, los galeotes lanzan guijarros al caballero manchego hasta que logran derribarlo de Rocinante. La caída del hidalgo no detiene la ola de violencia lúdica. Emulando la acción de la lanza quebrada por el mozo picado, un galeote golpea a don Quijote con su bacía hasta rompérsela en la espalda. El despedazamiento de la figura quijotesca termina cuando los galeotes, de forma semejante a cuando los reyes bufos eran despojados de las ropas, roban al caballero parte de sus prendas:

el alcance del episodio. Así es como la vertiente 'idealista’ o, por lo menos 'ética' de esta corriente interpretativa llega a ver, en la derrota de don Quijote, no tanto el fracaso de cualquier justicia natural y espontánea, sino las contradicciones infranqueables que suscita al pasar del plano de los valores ideales al de las realidades terrestres. Por su parte, su vertiente 'materialista' o, si se prefiere, 'política', juzga este fracaso como propio de una empresa utópica cuyo desenlace infeliz evidencia, de modo simbólico, que la vía revolucionaria es la única respuesta posible a los problemas que se plantea una sociedad real y concreta" (Canavaggio, 1979, p. 27).

13 En su análisis sobre la presencia de lo festivo en el Quijote, James Iffland ha planteado que la caracterización e interrelación de algunos personajes se construyen en torno al esquema de carnaval-cuaresmal. Siguiendo esta idea, Iffland interpreta el episodio de la liberación de los galeotes como la tradicional batalla entre el mundo carnal y el cuaresmal. Según el especialista, los encadenados y sus delitos representan "los excesos y debilidades de la carne", mientras los guardas simbolizan el "orden, la represión, la seriedad" (1999, p. 86). Sin embargo, el combate no puede comprenderse únicamente como el triunfo de lo carnal sobre lo cuaresmal o la inversión del orden jerárquico provocada por el espíritu carnavalesco. 
[...] No se pudo escudar tan bien don Quijote, que no le acertasen no sé cuántos guijarros en el cuerpo, con tanta fuerza, que dieron con él en el suelo; y apenas hubo caído, cuando fue sobre él el estudiante y le quitó la bacía de la cabeza y diole con ella tres o cuatro golpes en las espaldas y otros tantos en la tierra, con que la hizo pedazos [...] (I, 22, p. 247).

Es importante recalcar que la violencia que permea en el episodio no intenta contravenir al sistema punitivo. Por el contrario, el apedreamiento de los guardas cumple el propósito, mencionado al principio, de exorcizar a lo simbolizado de sus malogradas representaciones materiales. La jocosa eliminación de los elementos que perturban el orden social se halla también en el episodio del cuerpo muerto (I, 19).

\section{EL EXORCISMO FESTIVO DE LAS PRÁCTICAS DE RELIGIOSIDAD POPULAR}

Mientras viajan de noche, don Quijote y Sancho Panza se encuentran una multitud de lumbres en el camino. La primera impresión es que se trata de una procesión de ánimas en pena. Al ver de cerca el cortejo de personajes cubiertos con sobrepellices seguido de la litera enlutada, el hidalgo cree estar viviendo una aventura de andas, en las cuales los héroes caballerescos se topaban con una comitiva que transportaba un cadáver y debían vengar la muerte del difunto. Finalmente, las lúgubres huestes resultan ser un grupo de sacerdotes que trasladan un cuerpo de Baeza a Segovia.

Pese a la reacción del caballero y de su escudero, las procesiones nocturnas que deambulaban por los montes no constituían una realidad ficticia. Los numerosos testimonios sobre las comitivas de penitentes, las procesiones que portaban imágenes, las misas en descampados y otras manifestaciones de religiosidad popular dan cuentan de que dichas costumbres estaban muy extendidas en España durante los siglos XVI y XVII. Como respuesta a la efervescencia religiosa que recurría a estas expresiones externas de devoción, el movimiento reformador de la Iglesia intentó suprimirlas o ponerlas bajo el control de la jerarquía eclesiástica, ya que las consideraba poco devotas y sin utilidad (Arias de Saavedra Muñoz, 1998). Asimismo, las autoridades eclesiásticas acusaban a las prácticas de religiosidad popular de representar reviviscencias de elementos profanos. Incluso censuraban la participación de los religiosos que aprovechaban las peregrinaciones para cometer excesos carnales durante los viajes. 
Teniendo en mente este contexto, no resulta extraño que este grupo de sacerdotes enlutados se vuelva víctima de la violencia catártica. De manera simbólica, el caballero manchego - figura del mundo oficial - elimina a los personajes que constituyen la representación de la desviación de lo normado: la religiosidad popular. Ante la negativa de los encamisados para darle razones sobre el viaje que realizan y enmendar así el daño hecho, don Quijote decide arremeter contra ellos. Después de golpearlos con su lanzón, el caballero manchego justifica el ataque diciendo que ellos mismos tuvieron la culpa a causa de su aspecto y vestimenta ambivalente:

[...] que propiamente semejábades cosa mala y del otro mundo; y, así, yo no pude dejar de cumplir con mi obligación acometiéndoos, y os acometiera aunque verdaderamente supiera que érades los mesmos satanases del infierno, que por tales os juzgué y tuve siempre (I, 19, p. 204).

Los faldamentos, las lobas y las antorchas de los sacerdotes resultan elementos clave para la construcción de una atmósfera que convierte la erradicación de las prácticas de religiosidad popular en un juego de alegre hostilidad. El ambiente lúdico es subrayado por el término encamisados, el cual trae a colación la fiesta de la encamisada, caracterizada por comparsas de máscaras que bailaban y desfilaban con hachas durante la noche..$^{14} \mathrm{La}$ violencia se desata como una ola in crescendo que envuelve a todos los miembros de la procesión:

Todos los encamisados era gente medrosa y sin armas, y, así, con facilidad en un momento dejaron la refriega y comenzaron a correr por aquel campo, con las hachas encendidas, que no parecían sino a los de las máscaras que en noche de regocijo y fiesta corren. Los enlutados asimesmo, revueltos y envueltos en sus faldamentos y lobas, no se podían mover, así que muy a su salvo don Quijote los apaleó a todos y les hizo dejar el sitio mal de su grado, porque todos pensaron que aquel no era hombre, sino diablo del infierno, que les salía a quitar el cuerpo muerto que en la litera llevaban (I, 19, p. 202).

${ }^{14}$ Encamisada. 'la fiesta que se hace de noche con hachas por la ciudad en señal de regocijo, yendo a caballo, sin haber hecho prevención de libreas, ni llevar orden de máscara, por haberse dispuesto repentinamente, para no dilatar la demostración pública y la celebración de la felicidad sucedida' (Covarrubias, 1611, I, p. 363). Encamisada. 'Es cierto estratagema de los que de noche han de acometer a sus enemigos y tomarlos de rebato, que sobre las armas se pone las camisas, porque con la oscuridad de la noche no se confundan con los contrarios, y de aquí vino en llamar encamisada a la fiesta que se hace de noche con hachas por la ciudad en señal de regocijo' (Covarrubias, 1611, I, p. 693). 
La descripción de los encamisados como "máscaras que en noche de regocijo y fiesta corren" transfigura las prácticas de religiosidad popular en un acto hilarante. ${ }^{15}$ La violencia contra la procesión de sacerdotes no pretende irreverenciar los principios fundamentales de la fe ni la autoridad que ellos representan, sino solo una crítica generalizada a determinados comportamientos.

Sin importar quién sea el personaje que desate la violencia o la víctima que la padezca, la violencia lúdico-festiva persigue un mismo propósito: la eliminación catártica de los elementos anquilosados o conflictivos de la sociedad. La manera en que la violencia constituye una catarsis colectiva queda ejemplificada claramente en el fin del gobierno de Sancho Panza (II, 53).

\section{El DESPEDAZAMIENTO DEL PELELE SIMBÓLICO: EL FIN DEL UTÓPICO GOBIERNO}

En el Quijote, las ventas, el palacio ducal y la Ínsula Barataria son espacios donde se construye, de manera parcial, el reino de la utopía: la pérdida de los límites, la igualdad, la libertad y la abundancia. En el caso de las ventas y el palacio, los personajes —desde el cura Pero Pérez, Maese Nicolás, don Fernando, hasta el mayordomo, Altisidora y la servidumbre ducal — se desenvuelven en un ambiente de fraternidad y libertad. Empero, en la Ínsula, la instauración del falso gobierno escuderil da un paso más hacia los principios de la Edad Dorada. ${ }^{16}$ Las ordenanzas del gran gobernador Sancho Panza, orientadas hacia el bien común, ${ }^{17}$ conforman una propuesta terapéutica que repara, entre burlas y veras, las deficiencias sociales del mundo cotidiano:

\footnotetext{
15 Latergiversación burlesca de las exhibiciones de religiosidad mediante términos relacionados con el ámbito festivo ocurre también en el episodio de los cofrades que portan una efigie de la Virgen (I, 52). Don Quijote confunde a los disciplinantes con un grupo de follones que llevan a una dama cautiva. La figura de los disciplinantes, caracterizada por suvestimenta, es ridiculizada cuando el narrador los llama "ensabanados", que eran una "variante de encamisados que, enmascarados y envueltos en sábanas, andaban por las calles de noche, haciendo mil locuras” (Osterc, 208).

16 El tópico de la Edad de Oro remite a un modo utópico de existencia, libre de los vicios y las vicisitudes cotidianas. En la tradición griega, este reino aparece en Hesíodo (Los trabajos y los dias) y Arato (Fenómenos), mientras que la latina está presente en Ovidio (Las metamorfosis, I, pp. 76-115).

17 Respecto de la doctrina sociopolítica que sirve de trasfondo para el gobierno insulary la emulación paródica de los tratados políticos de la época, véase H. Chiong, 2008. El gobierno de Sancho ha sido estudiado desde múltiples perspectivas. Maravall (1976) valora la Ínsula Barataria como representación de la utopía del buen sentido del poder. De acuerdo con L. Osterc (1988), el gobierno de Sancho constituye un régimen popular y democrático influido por el utopismo humanista. En la misma vertiente, C. Park (2004) considera que la influencia de las ideas utópico-humanistas permea en varios pasajes de la novela. En cambio, M. Scaramuzza (1998), acerca del gobierno insular, analiza el gobierno como una utopía agro-pastoril basada en el retorno a la simplicidad primitiva.
} 
[...] aquella tarde la pasó Sancho en hacer algunas ordenanzas tocantes al buen gobierno de la que él imaginaba ser ínsula, y ordenó que no hubiese regatones de los bastimentos en la república, y que pudiesen meter en ella vino de las partes que quisiesen, con aditamento que declarasen el lugar de donde era, para ponerle el precio según su estimación, bondad y fama, y el que lo aguase o mudase el nombre perdiese la vida por ello.

Moderó el precio de todo calzado, principalmente el de los zapatos, por parecerle que corría con exorbitancia; puso tasa en los salarios de los criados, que caminaban a rienda suelta por el camino del interese; puso gravísimas penas a los que cantasen cantares lascivos y descompuestos, ni de noche ni de día; ordenó que ningún ciego cantase milagro en coplas si no trajese testimonio auténtico de ser verdadero, por parecerle que los más que los ciegos cantan son fingidos, en perjuicio de los verdaderos.

Hizo y creó un alguacil de pobres, no para que los persiguiese, sino para que los examinase si lo eran, porque a la sombra de la manquedad fingida y de la llaga falsa andan los brazos ladrones y la salud borracha. En resolución: él ordenó cosas tan buenas, que hasta hoy se guardan en aquel lugar y se nombran "Las constituciones del gran gobernador Sancho Panza” (II, 51, pp. 1052-1053).

Diríase, por lo tanto, que el desarrollo del mandato sanchesco ejerce un efecto purificante sobre las tierras de Barataria:

[...] y en siendo hora, vamos a rondar, que es mi intención limpiar esta ínsula de todo género de inmundicia y de gente vagamunda, holgazanes y mal entretenida. Porque quiero que sepáis, amigos, que la gente baldía y perezosa es en la república lo mesmo que los zánganos en las colmenas, que se comen la miel que las trabajadoras abejas hacen. Pienso favorecer a los labradores, guardar sus preeminencias a los hidalgos, premiar a los virtuosos y, sobre todo, tener respeto a la religión y a la honra de los religiosos [...] (II, 49, p. 1025).

No obstante lo expuesto, para completar la renovación de las prácticas normativas, la violencia catártica debe derrumbar al gobierno simulado, lo cual ocurre mediante el destronamiento de la figura emblemática del poder: el gobernante Panza. La batalla por la defensa de la ínsula constituye el marco idóneo para ello.

Los pobladores de la villa (representantes de la colectividad) llevan a cabo una representación parateatral para simular un ataque a la ínsula. Durante "la séptima noche de los días de su gobierno" (II, 53, p. 1061), Sancho es despertado y avisado de que la ínsula ha sido invadida, razón por la cual debe alistarse para protegerla. Al principio, él se niega a combatir, pero acaba aceptando ser el capitán de sus huestes, transfigurándose del gobernante Momo en el pelele Panza. 
De manera semejante a los rituales tradicionales, se prepara al gobernante Panza para que desempeñe el papel de chivo sacrificado. En las fiestas carnavalescas, al bufón se le disfrazaba con "los atuendos de rey" en el momento de ser coronado, y recibía una nueva indumentaria al terminar el reinado (Bajtín, 1998, p. 178). Igualmente, el inicio y el final del gobierno de Sancho están marcados por el cambio simbólico de atuendo. Al ser "coronado" gobernante se le viste con un traje "parte de letrado y parte de capitán” (II, 42, p. 968), y la pérdida de su identidad como gobernante bufo está marcada por la armadura ridícula con la cual se prepara para combatir en la batalla burlesca. La armadura de don Quijote es una emulación paródica de los modelos caballerescos; en cambio, la de Sancho lo equipara al típico pelele que es golpeado, quemado o ahogado durante las fiestas populares: ${ }^{18}$

Yalmomentole trujeron dos paveses, quevenían proveídos dellos,yle pusieron encimadelacamisa, sin dejarle tomar otro vestido, un pavés delanteyotro detrás, y por unas concavidades que traían hechas le sacaron los brazos, y le liaron muy bien con unos cordeles, de modo que quedó emparedado y entablado, derecho como un huso, sin poder doblar las rodillas ni menearse un solo paso. Pusiéronle en las manos una lanza, a la cual se arrimó para poder tenerse en pie. Cuando así le tuvieron, le dijeron que caminase, y los guiase, y animase a todos; que siendo él su norte, su linterna y su lucero, tendrían buen fin sus negocios (II, 53, p. 1062).

Es preciso recordar que la violencia ritualizada une a los participantes en contra de un blanco específico. De este modo, los pobladores toman parte, amparados por el igualitarismo de la oscuridad ("apagando las antorchas"), de la aniquilación lúdica del gobierno. La acción catártica de la sociedad se lleva a cabo cuando los habitantes pisotean y golpean con vehemencia al irrisorio representante del poder:

Por cuyas persuasiones y vituperios probó el pobre gobernador a moverse, y fue dar consigo en el suelo tan gran golpe, que pensó que se había hecho pedazos. Quedó como galápago, encerrado y cubierto con sus conchas, o como medio tocino metido entre dos artesas, o bien así como barca que da al través en la arena; y no por verle caído aquella gente burladora

18 "En Roma, elegíase un monarca que [...] algunos datos hacen suponer que [...] tenía un [...] fin trágico; todos los desenfrenos, todos los excesos le estaban permitidos, pero se le sacrificaba sobre el altar del dios-soberano, Saturno, a quien había encarnado durante treinta días. Ya muerto el rey del Caos, todo se reintegraba al orden, y el gobierno usual dirigía de nuevo un universo organizado, un Cosmos. En Rodas, al finalizar las Cronias, se sacrificaba a un prisionero previamente embriagado. En las Saceas babilónicas se ahorcaba o se crucificaba a un esclavo que durante la fiesta había desempeñado en la ciudad el papel de rey, utilizando a las concubinas de éste y dictando órdenes en su lugar" (Caillois, 1996, p. 140). 
le tuvieron compasión alguna, antes, apagando las antorchas, tornaron a reforzar las voces y a reiterar el "¡arma!" con tan gran priesa, pasando por encima del pobre Sancho, dándole infinitas cuchilladas sobre los paveses, que si él no se recogiera y encogiera metiendo la cabeza entre los paveses, lo pasara muy mal el pobre gobernador, el cual, en aquella estrecheza recogido, sudaba y trasudaba, y de todo corazón se encomendaba a Dios de aquel peligro le sacase (II, 53, p. 1063).

El mismo paroxismo del mozo picado y los galeotes afecta a los habitantes, quienes continúan con la representación de la batalla aun después de que Sancho cae al piso:

Unos tropezaban en él, otros caían, y tal hubo que se puso encima un buen espacio y desde allí, como desde atalaya, gobernaba los ejércitos y a grandes voces decía:

- ¡Aquí de los nuestros, que por esta parte cargan más los enemigos!

¡Aquel portillo se guarde, aquella puerta se cierre, aquellas escalas se tranquen!

¡Vengan alcancías, pez y resina en calderas de aceite ardiendo!

¡Trinchéense las calles con colchones!

En fin, él nombraba con todo ahínco todas las baratijas e instrumentos y pertrechos de guerra con que suele defenderse el asalto de una ciudad [...] (II, 53, pp. 1063-1064).

Considerando el efecto catártico de la violencia, no resulta extraño que la "victoria” sobre los invasores esté asociada con el despedazamiento (cuchilladas, golpes, pisotones) del gobernante pelele, quien a la usanza del entierro de la sardina que marca el cierre del ciclo festivo, Sancho se convierte en una simbólica carne de puerco que debe sepultarse para renovar el poder que representa.

El breve examen de las palizas, los apedreamientos y demás formas de violencia en el Quijote deja ver que ésta no sólo parodia el modelo de los combates caballerescos. A lo largo de la obra, una ola de violencia recorre el mundo donde se desenvuelve la pareja quijotesca, atrapando a su paso a diversos personajes y arrastrándolos como si de una marejada se tratara, ya sea como una forma de liberar las tensiones y rivalidades entre los miembros de la sociedad (el mozo picado, el vizcaíno), de exorcizar y aniquilar las imperfecciones del orden social (los guardas, los encamisados), o para regenerar las estructuras de la sociedad (el gobernante Sancho Panza). De igual manera que los habitantes de la vieja Venecia disfrutaban los diversos juegos de violencia festiva, los personajes del Quijote, por medio de los apedreamientos, las palizas y otras formas de violencia, restañan las heridas, solucionan conflictos e incluso se purifican como comunidad. 


\section{BibLIOgRAFÍA}

Arendt, H. (2006). Sobrela violencia. Trad. Guillermo Solana. Madrid, España: Alianza. Arias de SaAvedra, I., y López Guadalupe Muñoz, M. L. (1998). Auge y control de la religiosidad popular andaluza en la España de la Contrarreforma. En J. Martínez Millán (coord.). Felipe II (1527-1598): Europa y la monarquía católica (pp. 37-61). Madrid, España: Parteluz.

Bajtín, M. (1998). La culturapopular en la Edad Media y en el Renacimiento. El contexto de François Rabelais. Trad. Julio Forcat y César Conroy. Madrid, España: Alianza. Burke, P. (1996). La cultura popular en la Europa moderna. Trad. Antonio Feros. Madrid, España: Alianza [1978 1 $\left.1^{\mathrm{a}} \mathrm{ed}.\right]$.

Burke, P. (2000). Formas de historia cultural. Trad. Belén Urrutia. Madrid, España: Alianza.

Caro Baroja, J. (1979). El Carnaval. Análisis histórico-cultural. Madrid, España:

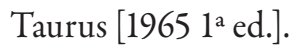

Caillois, R. (1996). El hombre y lo sagrado. Trad. Juan José Domenchina. Distrito Federal, México: Fondo de Cultura Económica.

Cervantes, M. de (1999). Don Quijote de la Mancha. Ed. Francisco Rico. Barcelona, España: Instituto Cervantes, Crítica.

Canavaggio, J. (1979). Burlas y veras en la aventura de los galeotes. Nueva reflexión sobre un episodio del Quijote. En Analescervantinos, tomo 18 (pp. 25-33). Madrid, España: Consejo Superior de Investigaciones Científicas, Instituto de Lengua Literatura y Antropología.

Chiong, H. (2008). Ínsula de buen gobierno: El palimpsesto guevariano en "Las Constituciones del gran gobernador Sancho Panza". Cervantes. Bulletin of the Cervantes Society of America, 28(1): 135-165. Recuperado de https://www.h-net. org/ cervant/csa/artics08/ChiongRiveros08.pdf.

Covarrubias Orozco, S. de (1995). Camisa. Encamisada. Tesoro de la lengua castellana o española. Madrid, España: Castalia. Recuperado de http://ntlle.rae.es/ntlle/Srv ltGUIMenuNtlle?cmd=Lema\&sec=1.0.0.0.0. http://ntlle.rae.es/ntlle/SrvltGUI MenuNtlle? $\mathrm{cmd}=$ Lema\&sec $=1 \cdot 1 \cdot 0.0 .0$.

Fernández Oblanca, J. (1992). Literatura y sociedad en los entremeses del siglo XVII.

Oviedo, España: Universidad de Oviedo, Servicio de Publicaciones.

GirARD, R. (1998). La violencia y lo sagrado. Trad. Joaquín Jordá. Barcelona, España: Anagrama. 
Girard, R. (2002). El chivo expiatorio. Trad. Joaquín Jordá. Barcelona, España: Anagrama.

Iffland, J. (1999). De fiestas y aguafiestas: Risa, locura e ideologia en Cervantes y Avellaneda. Madrid, España: Iberoamericana, Vervuert.

IM BERT, G. (1992). Los escenarios de la violencia: Conductas anómicas y orden social en la España actual. Barcelona, España: Icaria.

Le Roy Ladurie, E. (1994). El Carnaval de Romans: De la Candelaria al Miércoles de Ceniza 1579-1580. Trad. Ana García Bergua. Distrito Federal, México: Instituto de Investigaciones Dr. José María Luis Mora.

Maravall, J. A. (1976). Utopía y contrautopía en el Quijote. Santiago de Compostela, España: Pico Sacro.

Máreuez Villanueva, F. (1973). Fuentes literarias cervantinas. Madrid, España: Gredos.

Muir, E. (2001). Fiesta y rito en la Europa moderna. Trad. Ana Márquez Gómez. Madrid, España: Editorial Complutense.

OSTERC, L. (1988). Elpensamiento socialy politico del Quijote. Interpretación histórico-materialista. Distrito Federal, México: Universidad Nacional Autónoma de México.

PARK, C. (2004). La república utópica en el Quijote. Revista de Educación, número extraordinario, 177-187. Recuperado de http://www.revistaeducacion.mec.es/ re2004/re2004_14.pdf.

Redondo, A. (1998). Otra manera de leer el Quijote. Madrid, España: Castalia.

Rodrigo, M. (2003). La narrativización de la violencia. Quaderns del CAC (17): 1520. Recuperado de https://www.cac.cat/pfw_files/cma/recerca/quaderns_cac/ Q17rodrigo_ES.pdf.

Scaramuzza Vidoni, M. (1998). Deseo, imaginación, utopia en Cervantes. Roma, Italia: Bulzoni Editore.

Soria SESÉ, L. (2006). La hidalguía universal. Iura Vasconiae (3): 283-316. Recuperado de https://dialnet.unirioja.es/descarga/articulo/2222163.pdf

Torres, B. (2002) Cuerpo y gesto en el Quijote de Cervantes. Madrid, España: Centro de Estudios Cervantinos.

Torres, B., y Guillemont, M. E. (2008). Algunas consideraciones acerca de la violencia en el Quijote. En Tus obras los rincones de la tierra descubren. Actas del VI Congreso internacional de la Asociación de Cervantistas (pp. 719-746). Alcalá de Henares, España: Centro de Estudios Cervantinos. 